\title{
Theophylline Metabolism during the First Month of Life and Development
}

\author{
M. BONATI, ${ }^{(34)}$ R. LATINI, G. MARRA, B. M. ASSAEL, AND R. PARINI \\ Laboratory of Clinical Pharmacology, Istituto di Ricerche Farmacologiche "Mario Negri," Via Eritrea, 62-20157 \\ Milan, Italy IM. B., R. L.J; Second Department of Pediatrics, Medical School, University of Milan, Italy \\ IG. M., B. M. A.J; Newborn Unit, Department of Obstetrics and Gynecology, Medical School, University of Milan, \\ Italy [R. P.]
}

\begin{abstract}
Summary
The metabolic pathway of theophylline (T) was studied in 12 newborns, one young infant, six children, and three adult volunteers. $T$ was injected IV, and blood and urine samples were assayed for $T$, caffeine (C), and their metabolites by a high-pressure liquid chromatography technique. We confirmed the methylation of $T$ to $C$ in newborn infants but not in older subjects. Demethylation of T to 3-methylxanthine was found in the young infant, in children, and in adults, but not in newborns. The major products excreted by neonates were $T$, 1-methyluric acid, and 1,3-dimethyluric acid. Children excreted a larger fraction of methyluric acids than adults.

Renal and body clearance of $T$ and $C$ are reported and discussed in relation to the age.
\end{abstract}

\section{Speculation}

On the grounds of blood and urine samples from subjects treated with theopylline, our results could indicate that caffeine oxidation predominates over $\boldsymbol{N}$-demethylation, involving lower activity of the cytochrome P-450 monooxygenase system during the first month of life than in older infants or adults compared to data reported in literature for other drugs. Our results suggest different forms of enzymes are involved in these reactions.

Since its introduction in the treatment of apnea the disposition of theophylline $(\mathrm{T})$ has been well described, not only in children $(18-20,32)$ and adults $(10,11,13,15,16,22,26,29,30,31)$, but also in the premature neonate. Newborns eliminate the drug very slowly $(4,12,17,23,28)$ partially methylating it to caffeine (C) (7-9), a unique example of drug methylation in humans.

$\mathrm{T}$ is metabolized in the liver by the P-450-dependent microsomal system, which has been shown to be deficient in the newborn, in relation to several substrates $(25)$.

Methylxanthine metabolism has been studied in the adult ( 5 , $11,15,29-31)$ but except for the paper by Aldridge et al. (1) on caffeine no data have been published so far on children and neonates. This study was undertaken to: (1) further study the unusual metabolism of $T$ to $C$; (2) define the metabolic pattern of $\mathrm{T}$ in neonates; $(3)$ describe progressive changes of $\mathrm{T}$ metabolism during development.

\section{EXPERIMENTAL PROCEDURES}

\section{SUBJECTS}

Newborns. Nine prematurely born infants (gestational age, 29.5 $\pm 0.8 \mathrm{wk}$ ) and three full-term newborns were treated IV with $\mathrm{T}^{1}$ for prevention or management of severe episodes of apnea. The treatment schedule for these 12 patients $(1660.8 \pm 174.0 \mathrm{~g}$ body weight at birth) reflected previous experience $(4,17)$ : a loading

\footnotetext{
${ }^{\prime}$ Administered as its ethylenediamine salt (about $80 \%$ of $\mathrm{T}$ )
}

dose of $5.5 \mathrm{mg} / \mathrm{kg}$ of T IV followed by maintenance IV doses of $1.1 \mathrm{mg} / \mathrm{kg}$ every $12 \mathrm{hr}$. T therapy was started at different ages, from 1 to 22 days of life, and depending on clinical needs, it continued from 4 to 19 days.

The neonates came from a group at low "exposure" to C (cord blood concentrations $<1 \mu \mathrm{g} / \mathrm{ml}$ ) as defined by a preliminary study in which we measured $C$ concentrations in 122 cord blood samples. The distribution of $\mathrm{C}$ levels, arbitrarily divided in three groups, was: 51 samples, $1 \mu \mathrm{g} / \mathrm{ml} ; 61$ samples, between 1 and 5 $\mu \mathrm{g} / \mathrm{ml}$; and 10 samples, between 5 and $9.7 \mu \mathrm{g} / \mathrm{ml}$.

Children. Six asthmatic in-patients $(45.7 \pm 11.2$ months of life) were given $T^{1}$ IV according to the following schedule: $5 \mathrm{mg} / \mathrm{kg}$ loading followed by $1.5 \mathrm{mg} / \mathrm{kg}$ every $6 \mathrm{hr}$. Before and during $\mathrm{T}$ treatment, they were given no food containing methylxanthines. A young infant was treated with the same dose schedule.

Adult Volunteers. Three adult volunteers, aged 25 to 27 years, received an IV bolus of $180 \mathrm{mg} \mathrm{T} \mathrm{T}^{1}$ over $5 \mathrm{~min}$. They took no food or beverages containing methylxanthines for 7 days before the study.

\section{MATERIALS}

The following pure compounds were obtained: caffeine (blended sources) ${ }^{2} ;$ theophylline monohydrate, (Carlo Erba, Milan, Italy); 1-methylxanthine and 1,3-dimethyluric acid (Fluka AG, Buchs SG, Switzerland); 1-methyluric acid (Adams Chemical Co., Brown Lake, IL); 3-methylxanthine and 8-chlorotheophylline (EGA-Chemie KG, Steinheim, Federal Republic of Germany); Acetonitrile (Lihrosolv; Merck, Darmstadt, Federal Republic of Germany) was UV grade. Standard solutions were prepared according to Thompson et al. (30).

\section{METHODS}

Blood capillary microsamples $(0.1$ to $0.2 \mathrm{ml})$ were obtained in newborns by heel puncture around the midpoint of the urine fraction time interval (concomitantly, whenever possible, with samples necessary for clinical monitoring of the neonates) and throughout the chronic treatment in some of them to define the complete patterns of accumulation of $T$ and $C$. Blood was sampled from the radial vein in adults at various times after $T$ administration. No blood samples were taken from children. $T$ and $C$ were assayed in blood (or plasma) by the high-pressure liquid chromatography method previously described (6).

A total of 19 urine fractions were obtained from newborns from the fourth $T$ dose to approach theoretical steady-state conditions. Because of difficulties in collecting complete $(0$ to $12 \mathrm{hr}$ ) urine fractions from neonates, each collection period was shortened to about $7 \mathrm{hr}(6.9 \pm 0.5 \mathrm{hr})$ between each two consecutive doses. Urinary data are, therefore, expressed as the molar fraction of each compound relative to the total moles excreted during the

\footnotetext{
${ }^{2}$ Kind gift of the National Soft Drink Association
} 
interval considered. In blank urine samples randomly collected from some neonates, $\mathrm{C}$ levels were very low, and no $\mathrm{C}$ metabolites were detectable. Moreover, these infants were not breast fed, which excluded any outside source of methylxanthines (27).

Urine samples were collected from volunteers at different times over the $24 \mathrm{hr}$. T, C, and their metabolites were measured in urine by a method slightly modified from Aldridge $e t$ al. (1). Urine extracts were injected into a high-pressure liquid chromatography system $^{3}$ equipped with a reversed phase column (Hibar RP-8, 5 $\mu \mathrm{m}$; Merck). The samples were eluted with a linear gradient, starting from $0.5 \%$ acetonitrile in $0.5 \%$ acetic acid $(\mathrm{v} / \mathrm{v})$ in water, up to a final concentration of $5 \%$ of acetonitrile within $36 \mathrm{~min}$. The flow rate was $1.7 \mathrm{ml} / \mathrm{min}$, the UV detector was set at $273 \mathrm{~nm}$, and 8-chlorotheophylline was used as internal standard. An internal calibration curve of $0,5,10$, and $20 \mu \mathrm{g} / \mathrm{ml}$ of $\mathrm{T}, \mathrm{C}$, and metabolites was prepared for each run of about ten samples. The lowest measurable amount of the compounds was $0.5 \mu \mathrm{g} / \mathrm{ml}$ of urine.

Body clearance $\left(\mathrm{Cl}_{\mathrm{B}}\right)$ was calculated as $\mathrm{D} / \mathrm{AUC}_{0 \rightarrow \infty}$, and renal clearance $\left(\mathrm{Cl}_{\mathrm{R}}\right)$ was calculated as $\frac{\Delta \mathrm{Au} / \Delta \mathrm{t}}{\mathrm{C}_{\mathrm{p}}}$ where $\mathrm{D}=$ total dose; AUC $_{0 \rightarrow \infty}=$ area under the plasma (or blood) concentrations versus time curve calculated with the trapezoidal rule, extrapolated to infinity; $\Delta \mathrm{Au}=$ amount of drug excreted in urine during the interval $\Delta t ; C_{p}=$ plasma concentration at the midpoint of the urine collection time interval.

\section{RESULTS}

Figure 1 reports the similar patterns of accumulation in blood of $T$ and $C$ in premature newborn infants during $T$ therapy. $C$ appeared in blood from the second day (fourth dose), and its levels were never higher than those of $T$, i.e., about $50 \%$. When $T$ was stopped, C disappeared more slowly than $\mathrm{T}$.

The individual features and urinary metabolites for patients and volunteers are shown in the "Appendix." Mean figures for urinary excretion are reported in Figure 2. Percentage of molar fractions of $\mathrm{T}$ and metabolites in adult volunteers were essentially the same when calculated on a 7-hr basis (as for newborns) or on the complete $24-\mathrm{hr}$ collection. T was the main compound excreted by neonates $(45 \%)$, whereas in children, it accounted for $10 \%$ and in adults, $14 \%$.

The molar ratio of 1,3-DMU in adults and neonates was the same $(34 \%)$, but in children it was higher $(46 \%)$. 1-Methyluric acid too, was higher in children $(32 \%)$ than in newborns $(14 \%)$ and adults $(25 \%)$.

The monodemethylated metabolite of T, 3-MX, was found only in adults' and childrens' urine; newborns do not appear to produce it or at most only in trace amounts as documented by neonate 2 (see "Appendix").

In agreement with blood data, $\mathrm{C}$ was present only in urines collected from neonates.

Mean values for total body and renal clearances of $T$ and $C$ are reported in Table 1. We did not determine these parameters in children because ample information is available and is reported in the table.

The increase in body clearance from newborns to adults was more marked for $\mathrm{C}$ than for $\mathrm{T}$.

Renal clearance values were higher for $\mathrm{T}$ than for $\mathrm{C}$ in neonates and adults and slightly lower in adults than neonates. Ratios of renal to body clearance of $T$ for newborns and adults were, respectively, 0.43 and 0.11 , similar to the percentages of unchanged drug excreted in urine ( 0.45 and 0.14 , respectively); the same trend was seen for $C$. No relationship was found among newborns between gestational age, body weight, or number of doses and metabolic pattern or clearance figures. It is interesting to note that in two neonates (neonates 6 and 9; see "Appendix") urine fractions collected after the last dose of $T$ showed reduced $T$ and $C$ and $a$ parallel increase in uric acids.

${ }^{3}$ Perkin-Elmer Series 2/2.
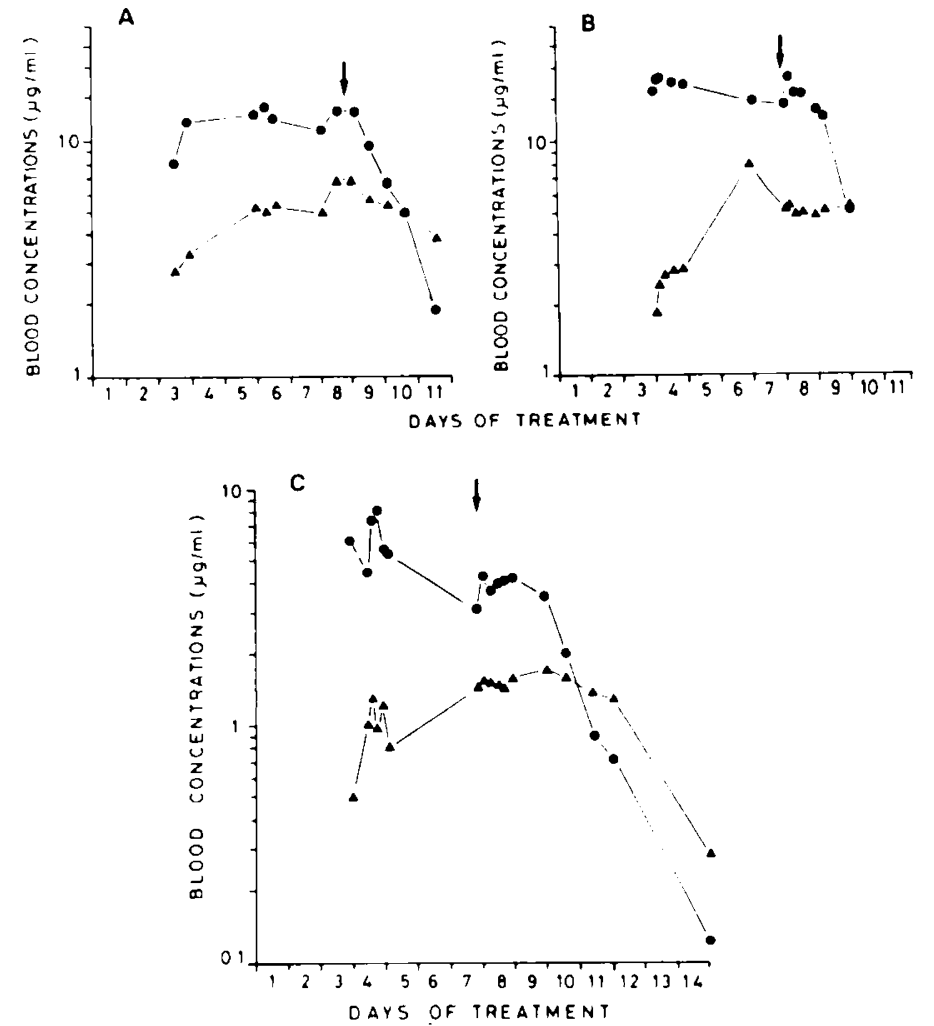

Fig. 1. Patterns of accumulation in blood of $T(\Theta)$ and $C(\Delta)$ in three premature newborns. Arrows, last T dose.

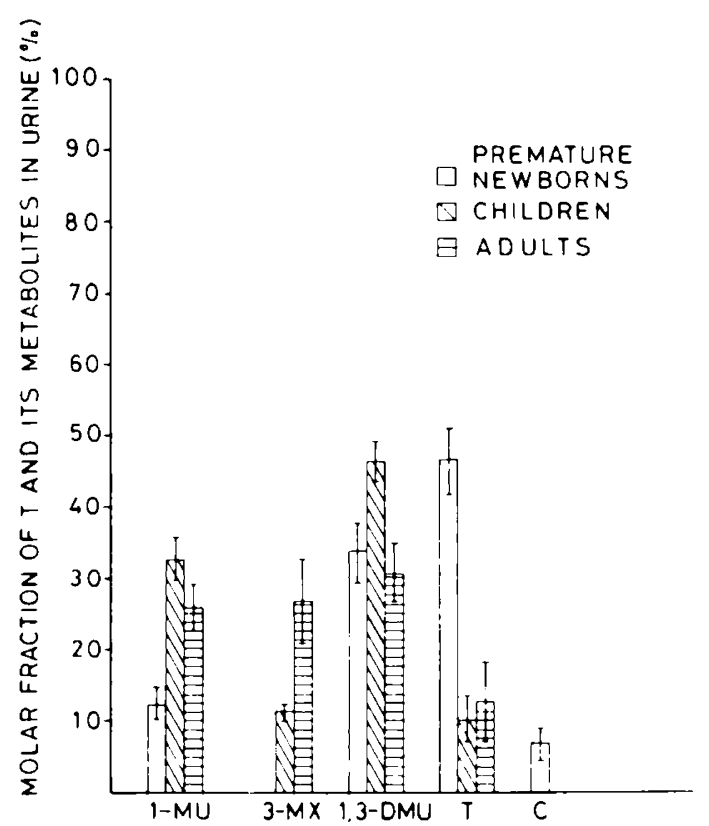

Fig. 2. Percentage of urinary molar fraction of $T$ and its metabolites for patients and volunteers.

\section{DISCUSSION}

Although acquired in a clinical setting with all the known limitations of a "classic" metabolic study, the data presented seem to describe quite well the metabolism of $\mathrm{T}$ at different ages. This is supported by the good agreement between our data and those published by other authors concerning cord blood $\mathrm{C}$ concentrations, clearance values, and metabolic pathway $(4,8,12,16,17$, $19,22,26)$. 
The presence of $\mathrm{C}$ even in very small amounts in cord blood of several neonates studied cannot have influenced $\mathrm{T}$ metabolic data because we never found any of the main $\mathrm{C}$ metabolites (dimethyluric acids) in blank urines examined, as was to be expected from the very low rate of metabolism of the compound in the first days of life ( $85 \%$ excreted unchanged in urine by newborns; see Ref. 1).

A very weak demethylation of $\mathrm{T}$ to $3-\mathrm{MX}$ in vitro by livers taken from human fetuses was recently reported (3). In vivo, however, the absence of 3-MX in urine of premature newborns, together with the presence of uric acids, even though in smaller amounts than in adults, indicates the predominance of $\mathrm{C}$ oxidation over $N$-demethylation in this age group.

Such observations are in agreement with the work by Horning et al. (14) and Aldridge et al. (1) who provided urinary metabolite data on C and confirm that the hepatic cytochrome P-450 complex involved in the metabolism of methylxanthines is deficient in the human neonate, as already reported in the literature for a number of substrates (25). However, this poor ability to form $\mathrm{N}$-demethylated metabolites is greater than that observed for other drugs such as diazepam (24) and mepivacaine (21), suggesting that different forms of cytochrome P-450 mixed function oxidases, each with a distinctive substrate specificity and maturational sequence, are involved.

Table 1. Mean clearance values of $T$ and $C$ at different ages

\begin{tabular}{|c|c|c|c|c|}
\hline \multirow[b]{2}{*}{ Subjects } & \multicolumn{2}{|c|}{$\mathrm{T}$} & \multicolumn{2}{|c|}{$\mathrm{C}$} \\
\hline & $\begin{array}{c}\mathrm{Cl}_{\mathrm{B}}{ }^{1} \\
\left(\mathrm{ml} \cdot \mathrm{hr}^{-1}\right. \\
\left.\mathrm{kg}^{-1}\right)\end{array}$ & $\begin{array}{c}\mathrm{Cl}_{\mathrm{k}} \\
\left(\mathrm{ml} \cdot \mathrm{hr}^{-1}\right. \\
\left.\mathrm{kg}^{-1}\right)\end{array}$ & $\begin{array}{c}\mathrm{Cl}_{\mathrm{H}} \\
\left(\mathrm{ml}^{-} \mathrm{hr}^{-1}\right. \\
\left.\mathrm{kg}^{-1}\right)\end{array}$ & $\begin{array}{c}\mathrm{Cl}_{\mathrm{R}} \\
\left(\mathrm{ml} \cdot \mathrm{hr}^{-1}\right. \\
\left.\mathrm{kg}^{-1}\right)\end{array}$ \\
\hline $\begin{array}{l}\text { Premature new- } \\
\text { borns }\end{array}$ & 14.5 & 6.2 & $10.0^{2}$ & 2.9 \\
\hline $\begin{array}{c}\text { Young infants ( } 3 \\
\text { to } 4^{1 / 2} \text { months) }\end{array}$ & & & $104.6^{3}$ & \\
\hline Children & $84.8^{4}$ & & & \\
\hline Adults & 42.5 & 4.8 & $88.7^{5}$ & $0.45^{5}$ \\
\hline $\begin{array}{l}{ }^{1} \mathrm{Cl}_{\mathrm{B}} \text {, body clea } \\
{ }^{2} \text { From A. Aldri } \\
{ }^{3} \text { From J. V. Ar } \\
{ }^{4} \text { From D. E. Za } \\
{ }^{5} \text { Unpublished }\end{array}$ & $\begin{array}{l}\text { ance; } \mathrm{Cl}_{\mathrm{R}, \mathrm{r}} \\
\text { dge et al. (1 } \\
\text { inda et al. } \\
\text { ske et al. ( } \\
\text { ata from th }\end{array}$ & $\begin{array}{l}\text { lal clearanc } \\
\text { laboratory. }\end{array}$ & & \\
\hline
\end{tabular}

The metabolic pattern of $\mathrm{T}$ was also determined in blood and urine of a 7-month-old infant treated with $\mathrm{T}$ for asthma (see "Appendix"). This was the only case in this age group, but the metabolic pattern was similar to that reported for children and adults. This agrees with the conclusions by Aldridge et al. (1), "the adult-like metabolite pattern (of C) of partially demethylated xanthines and urates was attained by 7 to 9 months of age."

Clearance values found for $T$ are in agreement with figures already reported in the literature for adults $(16,22,26)$ and neonates $(4,12,17)$. Although recently Aranda et al. (2) reported that "... plasma clearance of $C$ progressively increased and achieved comparable adult capacity by 3 to $4 \frac{1}{2}$ months and exceeded adult capacity by 5 - to 6 -month age ..." at the moment there are no data for $T$ in young infants. As far as we know, no data on renal clearance of $T$ and $C$ have yet been published either. The good agreement between clearance ratios and fraction of $T$ excreted unchanged in urine confirms the reliability of the calculated clearance figures.

Renal clearances of $\mathrm{T}$ and $\mathrm{C}$ were very low because of their extensive metabolism; $\mathrm{C}$ clearance in particular was lower than that of $\mathrm{T}$, probably because of the higher lipophilicity of $\mathrm{C}$, which increases the extent of tubular reabsorption of the compound. The partition coefficient between chloroform and $0.1 \mathrm{M}$ phosphate buffer, $\mathrm{pH} 4$ to 8 , was 8.578 for $\mathrm{C}, 0.382$ for dimethylxanthines, and 0.008 to 0.002 for other metabolites, so tubular reabsorption seems unlikely for these last compounds.

About fetal liver explant data (3), inasmuch as the amounts of 1,3-DMU and 3-MX produced are so low (pmoles) and the two conditions studied are so different, it is not possible to compare and discuss them in this context.

The larger fraction of uric acids in urine of children than adults suggests that the greater clearance of $T$ observed in this age group is probably due to the prevalent metabolism of $T$ to uric acids.

\section{CONCLUSION}

This study reports the metabolic pathway of $\mathrm{T}$ in premature newborns compared to children and adults (Fig. 3). T was mainly excreted unchanged in urine by neonates, and the major metabolites were 1-methyluric acid and 1,3-DMU. We found that $T$ was methylated to $\mathrm{C}$ only in the newborn group. However, demethylation to 3-MX was seen only in children and adults. This indicates that C oxidation predominates over $\mathrm{N}$-demethylation because of

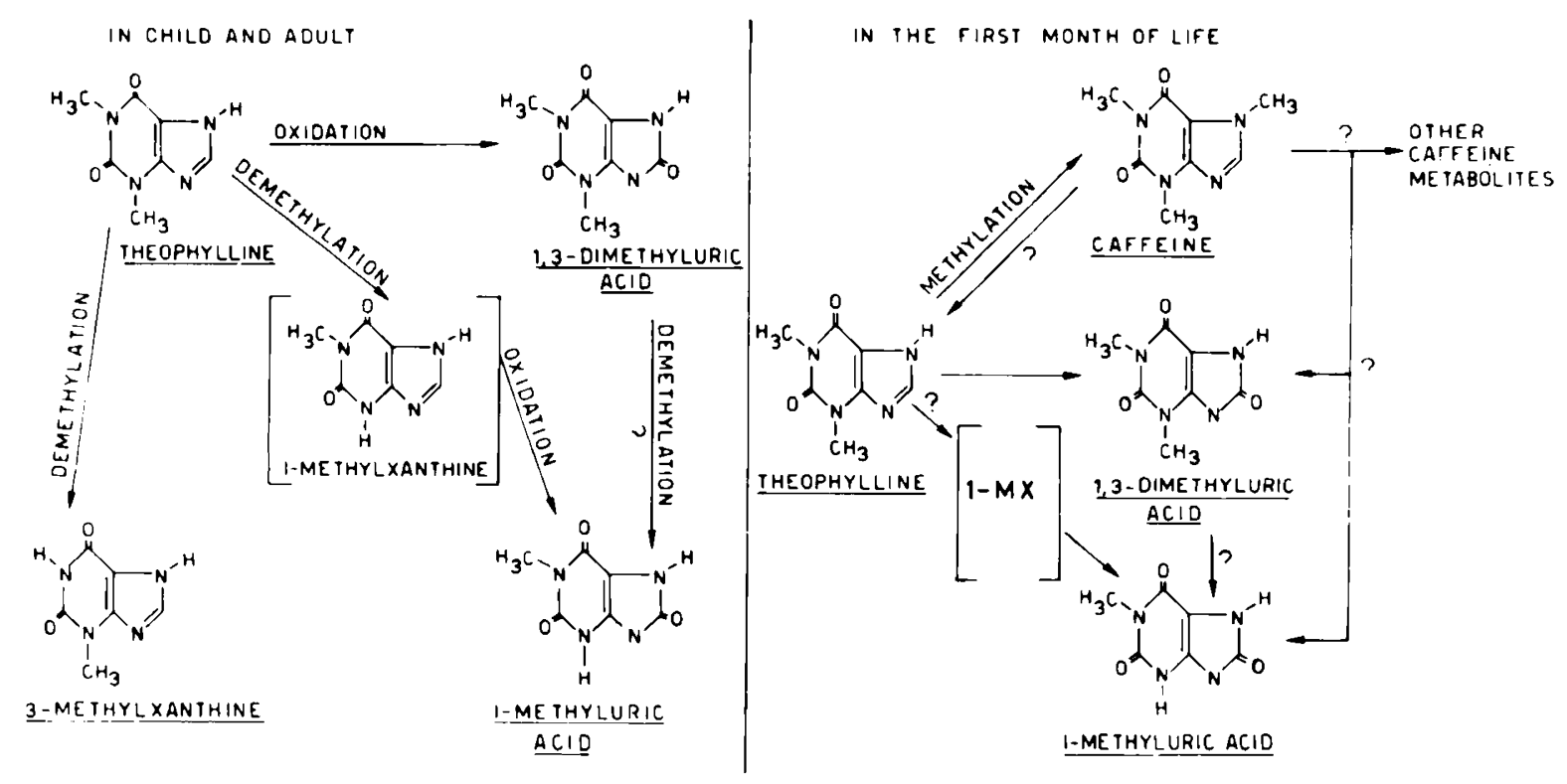

Fig. 3. Metabolic pathway of $\mathrm{T}$ in premature newborns, children, and adults. 
the lower level of activity of the cytochrome P-450 monoxygenase system in newborn infants than in children or adults. These findings suggest two further lines of research to ascertain when the methylative biotransformation of $T$ to $C$ disappears and when during the first year of life the metabolism of $\mathrm{T}$ approaches that of children and adults.

\section{REFERENCES AND NOTES}

1. Aldridge, A., Aranda, J. V., and Neims, A. H.: Caffeine metabolism in the newborn. Clin. Pharmacol. Ther.. 25: 447 (1979).

2. Aranda. J. W.. Collinge, J. M., Zinman, R., and Watters, G.: Maturation of caffeine elimination in infancy. Arch. Dis. Child., 54: 946 (1979).

3. Aranda. J. V.. Louridas, A. T.. Vitullo, B. B., Thom, P., Aldridge. A., and Haber, R.: Metabolism of theophylline to caffeine in human fetal liver. Science (Wash. D. C.). 206: 1319 (1979).

4. Aranda, J. V., Sitar, D. S., Parsons, W. D., Loughnan. P. M.. and Neims, A. H.: Pharmacokinetic aspects of theophylline in premature newborns. N. Engl. J. Med.. 295: 413 (1976).

5. Arnaud. M. J., and Welsch. C.: Metabolic pathway of theobromine in the rat and identification of two new metabolites in human urine. J. Agric. Food Chem. 27: 524 (1979)

6. Bonati. M.. Castelli, D., Latini, R., and Garattini, S.: Comparison of gas-liquid chromatography with nitrogen-phosphorus selective detection and high-performance liquid chromatography methods for caffeine determination in plasma and tissues. J. Chromatogr., 164: 109 (1979).

7. Bory, C., Battassat, P.., Porthault. M.. Bethenod, M.. Frederich. A.., and Aranda, J. V.: Biotransformation of theophylline to caffeine in premature newborn. Lancet, 2: 1204 (1978).

8. Bory, C., Baltassat, P., Porthault, M.. Bethenod, M.. Frederich, A.. and Aranda. J. V.: Metabolism of theophylline to caffeine in premature newborn infants. J. Pediatr.. 94: 988 (1979).

9. Boutroy, M. J., Vert, P., Monin, P., Royer, R. J., and Royer-Morrot, M. J.: Methylation of theophylline to caffeine in premature infants. Lancet, $I: 830$ (1979).

10. Brodie. B. B.. Axelrod, J., and Reichenthal. J.: Metabolism of theophylline (1.3dimethyl-xanthine) in man. J. Biol. Chem., 194: 215 (1952).

11. Cornish. H. H.. and Christman. A. A.: A study of the metabolism of theobromine. theophylline, and caffeine in man. J. Biol. Chem.. 228: 315 (1957).

12. Giacoia, G.. Jusko, W. J., Menke. J., and Koup. J. R.: Theophylline pharmacokinetics in premature infants with apnea. J. Pediatr.. $89: 829$ (1976)

13. Grygiel. J. J.. Wing. L. M. H., Farkas. J., and Birkett, D. J.: Effects of allopurinol on theophylline metabolism and clearance. Clin. Pharmacol. Ther.. 26: 660 (1979).

14. Horning. M. G.. Butler. C. M.. Nowlin. J.. and Hill. R. M.: Drug metabolism in the human neonate. Life Sci.. I6: 651 (1975)

15. Jenne, J. W., Nagasawa. H. T., and Thompson, R. D.: Relationship of urinary metabolites of theophylline to serum theophylline levels. Clin. Pharmacol. Ther., 19: 375 (1976)
16. Jenne, J. W., Wyze. E., Rood. F. S., and MacDonald. F. M.: Pharmacokinetics of theophylline. Application to adjustment of the clinical dose of aminophylline. Clin. Pharmacol. Ther., 13: 349 (1973)

17. Latini. R., Assael. B. M., Bonati. M.. Caccamo, M. L.. Gerna, M.. Mandelli. M.. Marini, A.. Sereni, F., and Tognoni, G.: Kinetics and efficacy of theophylline in the treatment of apnea in the premature newborn. Eur. J. Clin. Pharmacol., 13: 203 (1978).

18. Levy, G., and Koysooko, R.: Pharmacokinetic analysis of the effect of theophylline on pulmonary function in asthmatic children. J. Pediatr.. 86 : 789 (1975)

19. Loughnan, P. M., Sitar, D. S., Ogilvie. R. I.. Eisen. A.. Fox, Z., and Neims, A. H.: Pharmacokinetic analysis of the disposition of intravenous theophylline in young children. J. Pediatr. 88 : 874 (1976).

20. Maselli, R.. Casal, G. L., and Ellis, E. F.: Pharmacologic effects of intravenously administered aminophylline in asthmatic children. J. Pediatr., 76: 777 (1970).

21. Meffin. P.. Long, G. J.. and Thomas, J.: Clearance and metabolism of mepivacaine in the human neonate. Clin. Pharmacol. Ther. 14:218 (1973).

22. Mitenko, P. A.. and Ogilvie. R. I.: Pharmacokinetics of intravenous theophylline Clin. Pharmacol. Ther., 14: 509 (1973)

23. Morens. D. M.: The use of xanthines in treating apnea of prematurity. Pediatrics. 56: 617 (1975).

24. Morselli, P. L.. Mandelli, M. Tognoni. G.. Principi, N., Pardi, G... and Sereni, F. Drug interactions in the human fetus and in the newborn infant. In: $\mathrm{P}$. I Morselli. S. Garattini. S. N. Cohen: Drug Interactions. p. 259 (Raven Press, New York. 1974)

25. Neims. A. H.. Warner. M.. Loughnan. P. M.. and Aranda, J. V.: Developmental aspects of the hepatic cytochrome P450 monooxygenase system. Annu. Rev. Pharmacol. Toxicol.. 16: 427 (1976).

26. Piafsky, K. M.. Sitar, D. S., Rangno. R. E., and Ogilvie. R. I.: Theophylline disposition in acute pulmonary edema. Clin. Pharmacol. Ther.. $21: 310$ (1977)

27. Soyka. L. F.: Effects of methylxanthines on the fetus. Clin. Perinatol., $6: 37$ (1979)

28. Soyka, L. F.. and Neese. A. L.: Letter to the editor. Pediatrics, 56: 618 (1975).

29. Sved, S.. Hossie. R. D.. and McGilveray, 1. J.: The human metabolism of caffeine to theophylline. Res. Commun. Chem. Pathol. Pharmacol. 13: 185 (1976).

30. Thompson, R. D.. Nagasawa. H. T.. and Jenne, J. W.: Determination of theophylline and its metabolites in human urine and serum by high-pressure liquid chromatography. J. Lab. Clin. Med., 84: 584 (1974).

31. Warren, R. N.: Metabolism of xanthine alkaloids in man. J. Chromatogr.. 40. $468(1969)$

32. Zaske, D. E.. Miller. K. W.. Strem. E. L.. Austrian. S., and Johnson. P. B.: Oral aminophylline therapy. Increased dosage requirements in children. J. Am. Med. Assoc.. 237: 1453 (1977)

33. The authors are grateful to Dr. F. Tega from the Newborn Unit of the Magenta Hospital (Milan) who followed some of the cases reported.

34. Requests for reprints should be addressed to: Maurizio Bonati. Laboratory of Clinical Pharmacology. Istituto di Ricerche Farmacologiche. "Mario Negri." Via Eritrea. 62-20157 Milan. Italy.

35. This research was supported partially by the CNR (National Research Council. Rome, Italy) Convention on Clinical Pharmacology and Rare Diseases.

36. Received for publication March 21. 1980.

37. Accepted for publication July $28,1980$.

Appendix Individual features and urinary metabolites for subjects in the study

\begin{tabular}{|c|c|c|c|c|c|c|c|c|c|c|}
\hline \multirow[b]{2}{*}{ Subjects } & \multirow[b]{2}{*}{ Sex } & \multirow[b]{2}{*}{$\begin{array}{c}\text { Gestational } \\
\text { age (wk) }\end{array}$} & \multirow[b]{2}{*}{ Body weight (g) } & \multirow[b]{2}{*}{ Age $^{\prime}$} & \multirow[b]{2}{*}{$\begin{array}{l}\text { Adminis- } \\
\text { tration }^{2}\end{array}$} & \multicolumn{5}{|c|}{$\%$ molar fraction } \\
\hline & & & & & & $\begin{array}{l}\text { 1-Meth- } \\
\text { yluric acid }\end{array}$ & 3-MX & 1.3.DMU & $\mathrm{T}$ & $\mathrm{C}$ \\
\hline 1 & 0 & 35 & 2,250 & 2 days & 5 & 7 & $-{ }^{3}$ & 25 & 51 & 17 \\
\hline 2 & $q$ & 31 & 1,450 & 3 days & 4 & 2 & 5 & 35 & 53 & 4 \\
\hline 3 & $\delta$ & 32 & 1,450 & 3 days & 5 & 7 & - & 59 & 30 & 4 \\
\hline \multirow[t]{3}{*}{4} & q & 30.2 & 1,250 & 3 days & 6 & 14 & - & 52 & 31 & 2 \\
\hline & & & & 6 days & 12 & 9 & - & 30 & 55 & 5 \\
\hline & & & & 7 days & 14 & 42 & - & 37 & 11 & 10 \\
\hline 5 & $\delta$ & 27 & 900 & 3 days & 7 & 17 & - & 28 & 52 & 1 \\
\hline \multirow[t]{3}{*}{6} & $\delta$ & 30.4 & 1,600 & 5 days & 10 & 5 & - & 39 & 50 & 5 \\
\hline & & & & 7 days & $14^{4}$ & 5 & - & 20 & 57 & 17 \\
\hline & & & & 9 days & & 13 & - & 36 & 43 & 7 \\
\hline \multirow[t]{3}{*}{7} & $\delta$ & 34 & 2550 & 5 days & 5 & 8 & - & 71 & 17 & 3 \\
\hline & & & & 5 days & 6 & 9 & - & 47 & 44 & - \\
\hline & & & & 7 days & 7 & 27 & - & 46 & 15 & 12 \\
\hline \multirow[t]{2}{*}{8} & $q$ & 28 & 1,300 & 6 days & 10 & 6 & - & 16 & 62 & 16 \\
\hline & & & & 9 days & 16 & 8 & - & 18 & 55 & 19 \\
\hline \multirow[t]{3}{*}{9} & $\delta$ & 30.3 & 1,550 & 6 days & 12 & 2 & - & 2 & 96 & - \\
\hline & & & & 11 days & $22^{4}$ & 20 & - & 13 & 58 & 8 \\
\hline & & & & 15 days & & 46 & - & 38 & 14 & 1 \\
\hline 10 & $\delta$ & 30.8 & 1,780 & 7 days & 12 & 21 & - & 49 & 24 & 5 \\
\hline 11 & 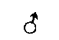 & 35 & 2,850 & 24 days & 4 & 6 & - & 32 & 61 & 1 \\
\hline 12 & 8 & 26 & 1,000 & 31 days & 32 & 16 & - & 13 & 61 & 9 \\
\hline$X \pm S . E$. & & $30.8 \pm 0.9$ & $1,660 \pm 172$ & $8.3 \pm 1.6$ & $10.7 \pm 1.6$ & $13.8 \pm 2.6$ & - & $33.6 \pm 3.7$ & $44.8 \pm 4.6$ & $6.9 \pm 1.3$ \\
\hline
\end{tabular}


Appendix-Continued

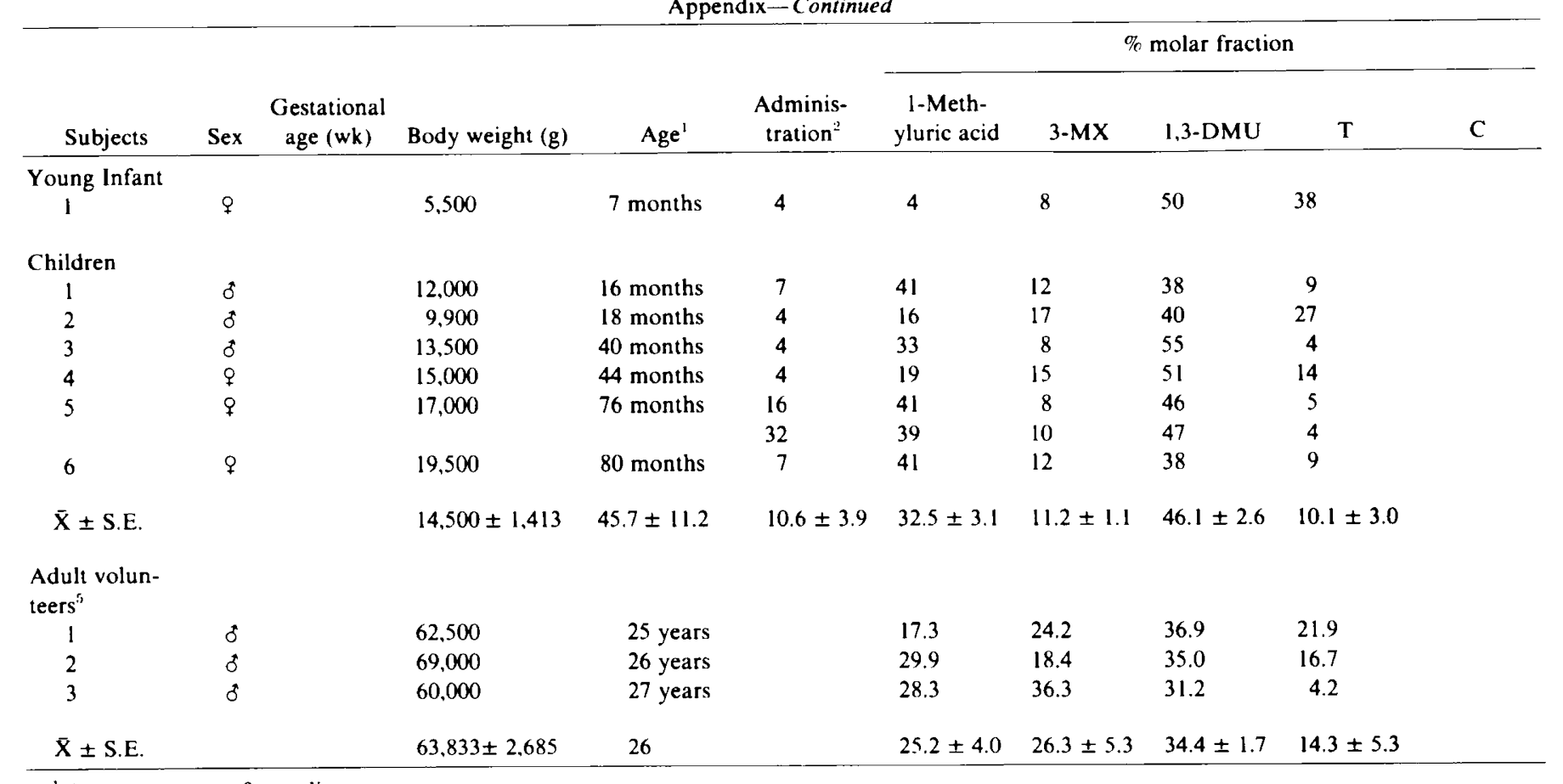

${ }^{1}$ Age at moment of sampling.

"Number of doses administered before the collected fraction.

3 - Not detectable.

${ }^{4}$ Last dose.

" 24-hr urine collection.

Copyright (1) 1981 International Pediatric Research Foundation, Inc $0031-3998 / 81 / 1504-0304 \$ 02.00 / 0$ 